\title{
Insurance of Medical Personnel Professional Responsibility as a Form of Legal and Social Responsibility
}

\author{
Dr.iur. Inga Kudeikina \\ Riga Stradins University, Faculty of Law, Latvia \\ Email: Inga.Kudeikina@rsu.Iv \\ Mg.iur. Karina Palkova \\ Riga Stradins University, Doctoral Department, Latvia \\ Email: Karina.Palkova@inbox.Iv
}

\section{Doi:10.5901/ajis.2016.v5n3s1p320}

\section{Abstract}

\begin{abstract}
Medical professionals are not protected from patients' action in the case of medical negligence or mistake. Anytime patient can file a medical malpractice claim against medical professional. Nowadays medical negligence claims and mistakes are increasing. The progress of medical law shows, that patients more often use the rights and legal options to protect their interests and fundamental rights. The scope of the freedom of medical professionals is limited. They have to act in accordance with certain standards or an artificially created frame and in the best interests of their patients and protect constitutional rights of each patient. In case when medical professionals make mistakes and the patients are harmed due to that claims can be brought. Medical professionals must have insurance or indemnity to protect themselves, but patients also need it. Patients' rights and possibility to compensate damage depends on how good and qualitative the medical professional liability insurance or indemnity is. Furthermore, medical professional's mistake is his or her own ethical, prestige and social responsibility in front of the patients' issue. In order to protect medical professionals and patients the medical professional insurance system has to cover healthcare practice and provide professional protection against the financial consequences of legal liability, as well as possible moral compensation. The objective of the paper is to present a summary of medical professional insurance system in Latvia. The article will provide information about what legal mechanisms shall be improved in order to optimize medical professionals' insurance system and patients' rights to receive compensation.
\end{abstract}

Keywords: medical professionals, professional liability insurance, patients

\section{Introduction}

An increasingly frequent opinion is highlighted that the level of public health depends on the available health care and health care quality. One of the prerequisites of the high-quality of received health care is patient's satisfaction with the services received and his state of health after them. In this case, attention is also paid to the fact whether the patient is satisfied with the assigned and safeguarded rights from the side of medical personnel and the quality of communication in general. ${ }^{1}$

The social aspect in the relationship between medical personnel and the patient is gradually becoming an important form of social relationship. It directly affects both of the following aspects: the patient's rights and desire to receive access to quality services, and medical practitioners' need to expand the boundaries of social activities to meet the legal interests of their patients.

However, there is a problem within the scope of activities of medical professionals. The independence of medical professionals is relative. The scope of the freedom of medical professionals is limited and does not give the rights to medical professionals to act freely. The persons have to act in accordance with certain standards or an artificially created frame. ${ }^{2}$

\footnotetext{
1 Филиппов Ю.Н., Эделев Н.С., Краев И.П., Абаева О.П., 2008

2 http://ejms.euser.org/index.php/all-volumes-ejms/january-april-2016-nr-2/387-issues-of-legal-organization-of-the-patient-health-careprofessional-relationship
} 
Medical professionals have to act in the best interests of patients and protect the constitutional rights of each individual patient. But what happens when medical professionals make mistakes? Are they protected enough? Medical professionals work with the main aim to deliver good quality healthcare. In case when they do make a mistake and a patient gets harmed because of this mistake, it is important that medical professionals have insurance or indemnity. It should be noted, that patients' rights and possibilities to compensate for the damage depend on how good, and what quality, the insurance of medical professionals' liability, or indemnity, is.

Poor quality of work from the side of medical professionals is a restriction of patient's fundamental rights. Medical professional's mistake is their ethics, prestige and social responsibility issue before the patients'.

Medical professionals are not protected from patients' reactions. A patient can file a medical malpractice claim against a medical professional at any moment. It should be noted that in today's medical negligence claims and mistakes are increasing. The progress of medical law shows that patients use the rights and legal options to protect their interests more and more.

More and more often patients' claims include requests regarding moral compensations accusing medical professionals of having caused them injury, or of not having provided necessary medical services. Also, contractual terms and conditions are usually requested by patients in the private sector. Patients have information regarding minimum health care standards and use the opportunity to protect their best interests.

In order to protect medical professionals, a professional medical insurance system is used, which covers healthcare practice and provides professional protection against financial consequences of legal liability. ${ }^{3}$

\subsection{Objective of the work and methods}

The objective of the work is to present a summary of the system of professional medical insurance in Latvia. The paper discusses the legal mechanisms to be improved, and deals with how the professional medical insurance system, as well as patients' rights to receive compensation, could be optimized.

The paper utilized descriptive, analytical and deduction-induction methods. Within these methods, legal acts are analyzed, opinions of legal scientists are recorded, and conclusions are drawn and suggestions made.

\subsection{Analyses}

National acts that regulate insurance system of medical personnel professional liability, are in force in Latvia.

In 2013, the Latvian Medical Treatment Risk Fund was established. The aim of the found is to provide opportunities for the patients to protect their rights and receive help outside of the court.

For medical professionals, it is an opportunity to protect themselves against the risks related to their professional activity and its possible consequences.

Financial resources are paid into the Medical Treatment Risk Fund by medical institutions. In addition to that, a research by Latvian insurance companies who provide professional civil liability insurance for doctors, was carried out.

Additionally, a medical practitioner may purchase a professional risk insurance of his or her civil liability. In this case, a medical practitioner will be able to protect him/herself by expanding the range of services offered by the insurer and the associated insurance packages, yet in this case one would have to reckon with the high levels of cost of such insurance.

\section{Legal and Social Responsibility of Medical Personnel}

During the research of relationship of medical personnel and patients that emerge from the parties' disputes concerning treatment process or damage incurred to patient's life health, one has to conclude that the chosen type of insurance by the medical professional has an important role in safeguarding patient's rights.

Depending on what type of professional risks the medical personnel covers, the patient has, or has not, rights to receive compensation for such aspects as, e.g., damages caused to his or her health during the treatment process.

This means that there must be balance between rights and responsibilities of medical personnel and patients. In order to create this balance, each of the parties must be aware of the importance of social responsibility by taking any 
decision.

Medical practitioner, in the very essence of his or her deeds, carries out public functions, which are based on socially responsible behavior.

The concept of social responsibility is vast. But at the same time there are lack of definition of social responsibility. ${ }^{4}$

Author Dyck, Robert G. states that social responsibility is positive live concept 'everyone's impacts everyone. At the same time author explains, that social responsibility is one's responsibility for one's impacts on society, meaning other humans and their organizations, rather than one-self only. ${ }^{5}$

The authors assert that one of the definitions of social responsibility pinpoints that it is the range of parties' obligations to exert necessary support for the society. Social responsibility is in a way ethical conduct that is focused on the relevant group of persons or towards the general public.

According to Paragraph 1 of the Code of Ethics of Latvian Doctor Association, fundamental principle of a doctor's activities is a of respect for human life, humanity and individual human rights, irrespective of person's nationality, race, religion, age, sex, political opinion and social status. Along with the rest of the community, a physician is responsible for the health of general public, its improvements and an equitable health care system. It should be noted the mentioned aspect directly points to the behavior of medical personnel - to defend the public interests.

Code of Ethics of Latvian Doctor Association has been based on the International Code of Ethics which in year 1993 was developed and confirmed by the Global Medical Association. Therefore, a similar interpretation of medical practitioners' social responsibility is also adopted internationally.

Actions of medical personnel an effect each individual. That is exactly why the medical personnel, upon choosing the professional liability insurance model for a person, should remember the institute of social responsibility. Medical practitioners cannot be fully protected against their possibly unintentional errors in the treatment process. Neither is the patient immune to doctor's errors. This also means that the doctor must be ensured that a patient harmed due to his fault is getting compensated in the highest quality and most efficient way. ${ }^{6}$

\section{Insurance of Medical Personnel in Latvia}

The liability insurance system itself has been spared serious analysis from a health policy perspective. The politics of liability insurance has been dominated by the offspring of the crisis of the 1970s. The system still exists because of transformation processes particular in professional liability. ${ }^{7}$

None of the medical practitioners are protected against accidents or mistakes. There is no doubt that each patient's clinical course is highly individual, so the treatment process is always associated with some degree of risk. As per statistical data of World Health Organization, medical errors take place in 8-12\% of hospitalization cases in countries of European Union. ${ }^{8}$

In 2013, amendments to the Act „On Practicioning Doctors” entered into legal force. These excluded the paragraph that requested the medical personnel to acquire mandatory third party liability insurance. So far, medical personnel had to take double occupational insurances. This was mandated by the Latvian Patient Rights Act. However, a Medical Treatment Risk Fund started operation on October 25, 2013. The established institution aims to provide an out-of-court opportunity for patients to reimburse for the damages incurred to patient's life or health during the process of health care.

That mentioned idea was taken over from the Scandinavian countries. Thus, the Latvian Parliament voted for creation of a state administered fund - Medical Treatment Risk Fund.

Medical Treatment Risk Fund is established in the national insurance scheme against the risks in the medical sector that provides medical personnel the opportunity to protect them from consequences possible from their professional activities. ${ }^{9}$

\footnotetext{
${ }^{4}$ Jackson P, Hawker B. 2001. Is Corporate Social Responsibility Here to Stay? http://kantakji.com/media/3452/z113.pdf (December 2016)

${ }^{5}$ Dyck, Robert G., and Matjaž Mulej. Social Responsibility : Methods, Dilemmas And Hopes. Sharjah, U.A.E.: Bentham Science Publishers, 2014. v, eBook Collection (EBSCOhost). Web. 19 Dec. 2016.

${ }^{6}$ Beauchamp, T. L. and N. E. Bowie, (eds): 2001, Ethical Theory and Business, 6th Edition (Prentice Hall, Upper Saddle River, NJ).

${ }^{7}$ Sage, William M. Health Affairs. Jul/Aug2004, Vol. 23 Issue 4, p10-21. 12p.

8 World Healt organization. Data and Statistics [Online] Available http://www.euro.who.int/en/health-topics/Health-systems/patientsafety/data-and-statistics ( December 16, 2016)

${ }^{9}$ R.Mucins "Latvian Treatment Risk Fund: legal aspects". Jurista Vārds (2013 /NR. 41 (792);
} 
According to the normative acts governing the Medical Treatment Risk Fund, ${ }^{10}$ the budget of Medical Treatment Risk Fund is replenished by both state and private medical institutions. Its amount is calculated yearly by the National Health Service by taking into account the employees of the relevant institutions, medical personnel, and the number of persons belonging to certain risk groups. On basis of such a system, a fund is established funds from which payments are carried out in case there are damages to patient's life or health.

Establishment of the aforementioned fund has also served as the reason to adopt amendments in the „Act on Practicioning Doctors", which were devised in accordance with what is determined in the Act on Patients' Rights about the Medical Treatment Risk Fund.

Until the establishment of Medical Treatment Risk Fund, the rights of patients to receive compensation for damage to life or health caused by medical personnel were relatively limited. The patient had the rights to take legal action against a medical practitioner or institution under the civil procedure. This means that the patient had to have financial means to submit the application to the court, as well as the means to get legal assistance in preparing the court application. In addition to that, the trial under the Latvian civil procedure can take up relatively long periods - up to 5-7 years. In international practice claims involving relative similar injuries usually take more than 5 years as well to be resolved. ${ }^{11}$

After creation of Medical Treatment Risk Fund, patients were given the opportunity to address the issue of damages to health or life suffered during health care under the administrative procedure.

Compensation may be obtained for damages incurred to patient's life or health in the treatment process, as well as for expenses associated with treatment to prevent or reduce adverse effects caused by the damages.

In accordance with Paragraph 16, part I of the Latvian Act on Patient's Rights, the patient has the rights to compensation for the damages incurred to his life or health (including moral damages), which by their action or inaction are caused by medical practitioners in a medical institution, or caused by the circumstances during treatment, as well as the rights to be reimbursed for expenses related to medical treatment, if such a treatment was necessary to prevent or alleviate adverse effects by a medical practitioner or medical conditions at the time of damage to the patient's life or health.

Paragraph 16, Part II of the Latvian Act on Patient's Rights stipulates that persons may receive compensation from the Medical Treatment Risk Fund in the following amounts:

1. for the damage incurred to his life or health (including moral damages) - in the amount of damage, but not more than EUR 142,290;

2. for the medical expenses caused to the patient - in the amount of the expenses, but not more than EUR 28,460 .

Unlike the cases of patient damages dealt with under the civil procedure, cases within the Medical Treatment Risk Fund about compensation for the damages to patient's life and health, and compensations for the patient's medical expenses, are assessed, and a decision is taken in six months from the date of application. In this case the examination period is many times shorter than under the civil procedure. Length of proceedings, if necessary, can be extended up to one year. However, it is only on the condition that the institution needs to request, collect and assess additional information in order to review the compensation claim and take a decision.

When examining the patient's complaint under the administrative procedure, the patient claims the compensation for damages to his life or health, as well as compensation for the medical expenses from the Medical Treatment Risk Fund no later than two years from discovering of the injury, but no later than three years from it occurred. This provision significantly restricts the patients' rights, unlike if the case was reviewed under the civil procedure.

An important aspect is the fact that according to Paragraph 16. Part II of Act on Patients' Rights, the compensations are not reimbursed if the patient has already received compensation for the damage to his life or health or for the medical expenses has already been received under a civil or criminal proceeding.

Another important aspect is that the patient is entitled to compensation for the damages incurred to his health irrespectively of whether the health service was received in a state, local communal or private medical institution.

On the bases of the aforementioned, it should be noted that the Fund significantly facilitates the possibilities for

10 Cabinet of Ministers Normatives No. 1268 "Regulations on Activities of Medical Treatment Risk Fund". [Online] Available: http://likumi.Iv/doc.php?id=262102 (December 18, 2016)

${ }^{11}$ R.R. Bovbjerg and A.Bartow, "Understanding Pennsylvania's Medical Malpractice Crisis: Facts about Liability, 2003 Insurance, the Legal System, and Health Care in Pennsylvania". Project on Medical Liability in Pennylvania June 2003 [Online] Available: http://www.urban.org/sites/default/files/alfresco/publication-pdfs/1000732-Understanding-Pennsylvania-s-Medical-Malpractice-Crisis.PDF (December 10, 2016) 
patients to assert their rights, on the other hand, it restricts them from exercising those rights, narrowing the range of patients' rights.

\section{Limitations of Compensation Receival - Lack of State-Required Medical Personnel Insurance}

Establishment of Latvian Medical Treatment Risk Fund gave the patients the opportunity to get compensation for medical personnel damages to the patients' health more quickly. However, there are cases where compensation from the Medical Treatment Risk Fund can not be obtained. For example, low-quality and nonexistent communication from a medical practitioner is not a case of injury or medical risk.

The Directive of March 9, 2011 of European Parliament and the Council no. 2011/24/EU on cross-border patients' rights defines the concept of health damage.

According to the Directive, it involves suffering, injury of physical or mental, illness or death that could have been prevented if at the time the patient came into contact with the health services, he/she had been provided with appropriate and adequate treatment.

This means that, under the Directive, one may apply for the compensation in the case when the damage caused to health could have been prevented. However, due to medical practitioner's action or omission of action, including during the supply of the service, it could not be prevented.

Compensation of Medical Treatment Risk Fund is not paid, if the existence of injury or a causal link between the damage and the action or omission of action of medical personal in the treatment process, is not detected.

At the same time, compensation can not be obtained if damage of organ or tissue, or disorder of anatomical function has relevance to the treatment, but has not been caused by unprofessional conduct of a medical practitioner. ${ }^{12}$

No compensation is available also in the case when the patient with intentional conduct has contributed to the suffered injury, increase of the amount of damage or refused from treatment.

No compensation of from the Medical Treatment Risk Fund is possible for transportation expenses incurred in order to arrive at the medical institution.

\section{Civil Liability Insurance of Medical Personnel}

Regardless of the fact that Medical Treatment Risk Fund is operational in Latvia, medical personnel may still purchase Civil Liability Insurance of Medical Personnel.

However, given the relatively small experience in Latvia in the field of professional liability insurance medical personnel, there are problems with the quality of liability insurance.

There is a practice in Latvia where insurance companies insuring the medical personnel for their civil liability, only reimburse for patients' direct, rather than moral damages. In addition, the proposed risk insurance range is not exhaustive and does not cover the potential risks which may face a medical practitioner. Provided that a medical practitioner wishes to obtain a well-developed civil insurance package, large payments must be paid for the service. Relevant professional liability insurance applied to health professionals is disproportionately expensive, and not always will it cover the risks that can potentially arise.

The private insurer usually pay not more than is strictly required by the law. Latvian Republic Civil Code provides for indirect losses, such as moral damages. Paragraph 2347 of Civil law reads that if a person inflicts a bodily injury upon another person through an action for which he or she is at fault and which is illegal, the first-mentioned person shall compensate the other person for medical treatment expenses and, apart therefrom and pursuant to the discretion of a court, also for potential lost income, and remuneration (material compensation) for moral injury.

The amount of moral demands is decided by the court at its discretion after the individual situation and practice. Admittedly, in the Latvian law practice there are not many cases of non-pecuniary compensation. ${ }^{13}$

Thus, also the attitude of private insurers in the treatment of moral damage compensation for patients is relatively modest and underdeveloped.

12 Cabinet of Ministers Normatives No. 1268 "Regulations on Activities of Medical Treatment Risk Fund". [Online] Available: http://likumi.Iv/doc.php?id=262102 (December 18, 2016)

13 Cabinet of Ministers Normatives No. 1268 "Regulations on Activities of Medical Treatment Risk Fund". [Online] Available: http://likumi.Iv/doc.php?id=262102 (December 18, 2016) 
If a medical practitioner chooses to purchase additional liability insurance, he must reckon with the following:

Insurers in the specific insurance cases often require from medical institution or the medical practitioner to provide more information on the patient, and often the whole case, including the documentation.

Documentation is requested until the trial takes place. However, the Medical Law stipulates that medical practitioners and authorities are not entitled to disclose information about the patient's treatment process until the case has been referred to the court.

It should be noted that private insurance companies do not reimburse to the buyer of insurance, namely the medical practitioner, the costs arising from a trial course.

From the point of view of safeguarding the patients' rights, there is a larger chance to receive compensation for the cases not covered by the Medical Treatment Risk Fund, by raising a civil claim against the medical practitioner. However, in this case the patient should expect the trial process will be much longer and more complicated as the process will include both the patient, the medical practitioner and the insurance company.

The patients are able to influence insurance system quality as well. If patients are active enough and protect their own interests bringing particular cases before the court, they make changes in the system. The insurance companies usually make changes in the costs of insurance for medical professionals. The changes are based on the patients level of activity. ${ }^{14}$

\section{Results}

Authors came to the following results:

1) the rights to protect Latvian medical professionals from the legal liability using professional insurance system are restricted;

2) patients have several legal ways how to claim medical malpractice against medical professional, but there are some restrictions regarding to amount of compensation;

3) there are legal problems according to medical professionals' insurance system quality;

4) the quality of health care system and patients' rights protection depends on how free medical professionals feel.

\section{Conclusion}

Provision of medical personnel professional liability insurance is a huge and important step on the legal relationships between medical personnel professionals and insurance companies. But, it should be noted, that more important point of the medical personnel professional insurance system is social relations created between medical professionals and patients. Medical personnel liability insurance is security not just medical professionals, but for patients as well. The security is multifunctional, from the one hand this security provides to both parties monetary benefits, on the other hand social responsibility.

There are several problems in Latvia regarding patients' possibility claim for compensation in case when medical professionals make mistakes and the patients are harmed due to that claims can be brought. Patients can claim administratively, using Latvian Treatment Risk Fund, or use civil proceedings. Both ways have to be researched deep enough to make final conclusion.

The question about social responsibility comes out. What kind of professional liability insurance is directed to protect patients' rights in the best way. Form the social responsibility contest medical professional have to take into account the best interests of the patients when such disputes arise.

\section{References}

Auerbach, D. I., Brantley, I., Heaton, How Will the Patient Protection and Affordable Care Act Affect Liability Insurance Costs?. Santa Monica, CA: RAND Corporation. P., \& Institute for Civil Justice, (. (U.S.). (2014);

Bovbjerg R.R. and A.Bartow, "Understanding Pennsylvania's Medical Malpractice Crisis: Facts about Liability Insurance, the Legal System, and Health Care in Pennsylvania". Project on Medical Liability in Pennylvania June 2003;

Beauchamp, T. L. and N. E. Bowie, (eds): 2001, Ethical Theory and Business, 6th Edition (Prentice Hall, Upper Saddle River, NJ);

Dyck, Robert G., and Matjaž Mulej. Social Responsibility: Methods, Dilemmas And Hopes. Sharjah, U.A.E.: Bentham Science Publishers, 2014. v, eBook Collection (EBSCOhost).

Sharma J and Bhushan V. Medical. Negligence \& Compensation. 2 nd. Edition. New. Delhi: Bharat Publications; 2004;

${ }^{14}$ Auerbach, D. I., Brantley, I., Heaton, How Will the Patient Protection and Affordable Care Act Affect Liability Insurance Costs?. Santa Monica, CA: RAND Corporation. P., \& Institute for Civil Justice, (. (U.S.). (2014). 
Sage, William M. Health Affairs. Jul/Aug2004, Vol. 23 Issue 4, p.10-21. 12p.

Jackson P, Hawker B. 2001. "Is Corporate Social Responsibility Here to Stay?"

R.Mucins "Latvian Treatment Risk Fund: legal aspects". Jurista Vārds (2013 /NR. 41 (792);

Филиппов Ю.Н., Эделев Н.С., Краев И.П., Абаева О.П., 2008;

Latvian Law On the Rights of Patients No 205, dated 17.12.2009;

Latvian Civil Law, date 14.10.1998. 